\title{
Ảngel Felicísimo Rojas visto por sí mismo y por los demás...
}

\author{
Fausto R. Aguirre T."
}

\author{
“Gloria a Loja, procure el lojano". \\ Ángel Felicísimo Rojas, \\ ha sido el mejor alumno \\ que aprendió esta lección
}

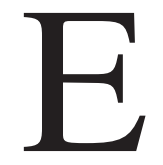

sta puerta de entrada a la obra de un hombre de dimensión literaria nacional e hispanoamericana, está evidenciada con testimonios en tanto aparecen como pruebas, justificaciones y comprobaciones de la certeza o verdad de lo que se dice o de lo que se expone en la edición de las OBRAs COMPLETAS de Rojas. Todo esto lo trabajamos a base de las declaraciones hechas y dichas por sí mismo, por el hombre que es autor y dueño de una obra contundente, y dicho también por amigos, intelectuales, estudiosos, conocedores de la obra de Á. F. Rojas. A esto se suman declaraciones de parientes muy próximos al autor.

En cada caso, con el soporte de los registros magnetofónicos: de la palabra e imágenes, recogidos por más de un cuarto de siglo que los he tenido con el autor, por instancias investigativas aprovechadas por las estancias del autor cuando retornaba a Loja, o recogidas en Guayaquil, en la ciudad de su habitual residencia o, en otras ciudades en las cuales coincidían nuestros encuentros por motivos eminentemente académicos e intelectuales.

En lo que he llamado puerta de entrada a la obra del Dr. Ángel Felicísimo Rojas, ciertamente, no coloco aquí criterios, materiales y declaraciones de estudiosos y amigos -que ellos esperen para otros enfoques, nuevas entregas y nuevos estudios de la obra del hombre-, esos

\footnotetext{
* Miembro de Número de la Academia Ecuatoriana de la Lengua correspondiente de la Real Española de Madrid.
} 
materiales se los presentará cuando destaquemos nuevos aportes de Rojas: su periodismo de opinión que está repartido en el diarismo nacional, en revistas y hemerotecas nacionales e internacionales y la rica correspondencia que tuvo el autor de EL ÉxOdo DE YANGana con distintos sectores intelectuales, políticos, familiares y con amigos. Otra será la realidad después de la entrega de estas Obras completas que, de suyo terminan perdiendo su razón de ser completas, porque nos quedan y nos restan otros materiales por rescatarlos y procesarlos, en la óptica de recoger una obra significativa: nuevos ensayos y su labor de periodista de opinión, trabajada por el académico don Ángel Felicísimo Rojas.

La primera parte de esta relación marcará los criterios, conceptos y respuestas que Rojas los dio en entrevistas concedidas a mi persona. La segunda parte presentará, asimismo, una síntesis de los criterios, eminentemente humanos, dados por los amigos y parientes muy próximos a él.

\section{9:}

Nace en Loja. El Plateado, recinto rural cerca de la ciudad de Loja, capital de la provincia de igual nombre.

\section{4:}

Inicia los estudios en la escuela primaria: Instituto Miguel Riofrío. Su madre, Doña Filomena, es su primera profesora quien enseñará a su hijo las primeras letras. Doña Filomena es maestra en la única escuela de El Plateado. Con fines religiosos, para cumplir con el sacramento de la primera comunión, "para que el chico" pueda memorizar la doctrina cristiana -requisito de la época-, estuvo un año en la escuela de los Hermanos Cristianos". - "Me confesé y comulgué, hice la primera comunión, que también ha sido la última”, expresa el Dr. Á. F. Rojas, con cierto aire de ironía.

"Me fue muy mal en esa escuela, porque me tocó un hermano cristiano que era francés y seguramente tenía una serie de complejos y era tiránico con los niños". "Este hermano me castigaba siempre haciéndome hincar de rodillas, porque yo le hacía preguntas que él las consideraba maliciosas o pecaminosas. Eran cuestiones y enunciados de la doctrina cristiana: esas que dicen que "los enemigos del alma son tres: mundo, demonio y carne y, como todo niño curioso, yo siempre le preguntaba 
¿Qué tipo de carne, maestro?". "Igualmente, cuando le preguntaba por significados de las palabras, porque no usaba diccionario todavía, ¿qué era fornicar? La respuesta era la imposición de otra arrodillada".

- ¿Por qué hizo sus estudios en una institución confesional de Loja?

- Fausto, yo me eduqué en una institución laica, en el Instituto Miguel Riofrío. La escuela de los hermanos lasallanos, en mi vida, fue una instancia de paso obligado, para que me preparen para la primera comunión. Tenía que respetar los designios y creencias de mamá y de mi familia.

\section{8:}

En Loja, se inicia como aprendiz de tipógrafo en la imprenta del Sr. Pablo Vélez. -"Trabajo las tardes de los días miércoles, sábados y domingos, haciendo un bisemanario curuchupa...".

\section{0:}

A los diez años de edad inicia los estudios de secundaria y lo hace en el colegio San Bernardo, hoy Colegio Experimental Bernardo Valdivieso. "Los que iniciábamos primer año en el colegio, éramos unos 'pobres mocosos', ninguno nos hacía caso de nada. Los grandes nos pegaban...".

\section{4:}

- "Más tarde, cuando comencé a ganar treinta sucres mensuales, en calidad de ayudante del gabinete de física y química del Bernardo "es que fui buen alumno en física" [se ríe], me independicé del trabajo de tipógrafo". "Solo allí mi mamá salió de El Plateado y vino a Loja. Estaban a mi cargo mi mamá, mis dos hermanas y mi abuelita. Pero, la carga no era exclusivamente mía; pues, mi mamá era muy industriosa y cooperaba muy bien". Ángel Felicísimo hacía el cuarto curso en el colegio San Bernardo.

\section{- ¿Estudió literatura en alguna Universidad?}

- "No, Fausto. Hice Jurisprudencia en la Universidad Nacional de Loja. Era lo único posible para la economía de mi casa. No podía ir a Quito, como lo hacían personas que tenían recursos y posibilidades económicas". 
1926:

- En este año, una Asamblea Nacional, reunida en Quito, establece el Partido Socialista Ecuatoriano. ¿Fue esta motivación del nacimiento del partido para que la juventud de aquella época se dedicara a la "ilustración” de un pensamiento e ideología del totalitarismo, de las líneas y acciones de izquierda?

- No necesariamente, Fausto. Mi vida de colegio, por la auténtica guía de los maestros que los tuve allí, marcó, un proceso de enseñanza suprema, orientadora y bien puesta. Tuvimos, con la dirección de ellos, muchas lecturas, definitivamente orientadores sus consejos y las lecturas. Sus lecciones y charlas extraclase fueron francas, y nos condujeron a penetrarnos aún más en el conocimiento de las líneas y tendencias de la ideología social.

- Es preciso reconocer que nuestra inclinación al socialismo fue, al inicio, un tanto sentimental. Rojas, tal vez, no habría podido decir, en materia de credo ideológico-político, a la usanza de Saramago: "Soy un comunista hormonal". Más tarde se reforzó intelectualmente. Se fundó el partido y yo obtuve mi inscripción al socialismo. Tenía mis dieciséis años de edad. Funcionó y funcionaba muy bien la célula socialista en Loja. Hicimos mucho trabajo de concienciación con los obreros y artesanos; caminábamos, siempre buscando el camino justo. En Loja hubo y hay muchas posibilidades de esa ansiada transformación social.

- Obreros, artesanos y campesinos estuvieron muy influidos por la Iglesia, que funcionó mucho más reaccionaria y determinante que en la actualidad. El dominio y la presión del clero eran tan profundos, tan fuertes que la gente veía con terror la educación laica, la consideraba como la enemiga de la espiritualidad humana. Pues, esto, no tiene que vérselas en nada con la religión.

- Se puso de moda en nuestro país, desde la influencia del triunfo liberal de 1875, la palabra 'masón', 'francmasonería' -todo esto de origen francés. Los conceptos 'liberal', 'libertad', 'laicismo', nunca se los tomó como actitudes del hombre ante la vida, en un mundo de interrelaciones humanas. Comenzaron a madurar los conceptos como oposición y negación de una religión y, sobre todo, poco a poco se fue fundamentando como una interpretación de economismo: -doctrina que concede a los 
factores económicos primacía sobre los hechos históricos de otra índole.

A la francmasonería, a la asociación secreta de personas que profesan principios de fraternidad mutua, a los que usan emblemas y signos especiales, y se agrupan en entidades llamadas logias, y a los que participábamos de células socialistas se la tenía como logia de mucha peligrosidad en contra de la religión. el Dr. Rojas, a la fecha de esta entrevista, se había desafiliado del Socialismo ecuatoriano, del cual fue su miembro fundador. He querido decir que la derecha y los conservadores veían en nosotros a unos contumaces enemigos destructores de las doctrinas de la fe y de la iglesia. No lo podíamos hacer, no era ese nuestro objetivo; nuestro trabajo caminaba otras rutas. Nos tomaban como gente indeseable que tenía un convenio con los diablos. Afirmaban, sostenían y decían vernos que teníamos reuniones en las noches de luna llena y clara; que besábamos el trasero de un chivo negro que era el diablo.

- Los compañeros obreros, artesanos, carpinteros... mantenían que el 19 de marzo, día de San José carpintero, era su día de descanso y festivo. Nosotros propugnábamos que el artesano se reconozca como tal y que debe ser el uno de mayo la fiesta del obrero. Cambiar estas concepciones y actitudes en ciudades de la Sierra y Costa, no fue nada fácil: nuestra tarea fue bastante ardua, dura, sobre todo, demandó mucho tesón de nuestra parte.

- Dr. Ángel Felicísimo, en el mismo año de la fundación del Socialismo como partido, en nuestro país, llega la Misión Kemmerer. ¿Se constituye esto como la contraparte capitalista que llega al país para asesorar económica y administrativamente y que va a proponer medidas de reordenamiento financiero? ¿Se quiere frenar, desde un inicio, el naciente socialismo?

- Sí. El país, a la fecha, vive el gobierno del Dr. Isidro Ayora, nombrado como presidente provisional por el ejército. Por influencia de la Misión Kemmerer, al año siguiente, se crea el Banco Central del Ecuador, la Superintendencia de Bancos, el Banco Hipotecario. Este es un antecedente del sistema de los bancos de Fomento. Se crea la Contraloría General de la Nación. Comienza a funcionar la Caja de Pensiones. Se inicia el funcionamiento de la Dirección General de Aduanas, casi 
seguidamente, la Dirección del Tesoro -más tarde llegará a ser Ministerio-; se pone en marcha la Dirección Nacional del Presupuesto, de Vías Públicas, de Ingresos, etc.

- Funciona el Ministerio de la Guerra, y como un hecho apendicular de éste, se crea el Departamento de Aviación, con la coordinación de Pedro Traversari. Se tiene una nueva Ley de Monedas que fija como respaldo económico el patrón oro, con la paridad cambiaria de cinco sucres por dólar. Por influencia de la Misión Kemmerer en este gobierno se decretan muchas leyes de gran contenido social que, sin embargo, van a ser maltratadas, cuyo fin y destino, se convertirán en nuevas mordazas de la sociedad.

1927:

- De manera que, Dr. Á. F. Rojas, ¿faltaba todo en nuestro país? Por ejemplo, ¿qué comienza a hacer la literatura de la época?

- No sé si faltaría todo. La vida burocrática de una nación es así. Siempre programa y crea nuevas funciones desechando otras sin mayor análisis, sin mayor evaluación para definir su valía o no importancia. Asimismo se crean otras instancias para la vida pública sin un mayor diagnóstico. En el ámbito de la literatura se ha comenzado a trabajar desde hace mucho. Hay serias propuestas. Desde el compatriota Dr. Miguel Riofrío, con la novela LA EMANCIPADA, hasta la literatura de los años treinta que han marcado toda la pauta de técnicas, conceptos y recursos, modelos ideológicos especiales, todo un desarrollo...

- Por otro lado, Fausto, por ejemplo, con seguridad, Pablo Palacio, con los cuentos que integran su novel libro de la época, UN HOMBRE MUERTO A PUNTAPIÉS, nos ayuda a caracterizar ya la descomposición social de aquel entonces. Es crítica la realidad.

- ¿Dr. Ángel Felicísimo, usted ha comenzado a escribir, para dar testimonio de una época?

- Si, Fausto, y lo hago con alguna modestia... Iniciamos nuestro trabajo de "agricultores de escritorio". Hubo una migración española con gente de mucho valor. Pudo dejar en nuestro país una huella imborrable culturalmente. El Ministerio de Relaciones Exteriores de la época consideró un hecho que no procedía dar cabida a gente capaz, versada cultural e 180 
intelectualmente. Los inmigrantes vinieron presididos por el hoy famoso escritor norteamericano John Dos Passos. Y, nuestro Ecuador les cerró el paso, tanto al escritor como a los inmigrantes. ¡Qué barbaridad! Esta gente que inicialmente eligió Ecuador, más tarde fue acogida por Chile y México, en donde dejaron una huella cultural de gran importancia. Se perdió la posibilidad de recibir la influencia cultural solo por la gazmoñería e influencia del clero. Se sostenía que todos esos exiliados eran una banda de comunistas sin ley ni Dios. Después llegaron nuevos inmigrantes; un grupo de españoles, llegó a su ciudad [Cuenca] y Ud. sabe que esos españoles competentes, humanistas de formación, han posibilitado excelentes resultados de desarrollo intelectual.

\section{8:}

Escribe por entregas [folletines]: CoRrerías CaSUALES POR EL ECUADOR. Su vehículo es El Heraldo del Sur, diario lojano.

- Sus Correrías CaSuales POR El ECUAdor es la mejor información que he obtenido respecto de sus primeras publicaciones, ensayos, estudios. Y este libro que sí es un verdadero ensayo sobre la realidad cultural y antropológica ecuatoriana.

Bueno, primeramente, creo en mi innata vocación de escritor, y creo también, más que nada, en el proceso de formación y lecturas que tiene el hombre y lo van convirtiendo como tal, porque yo comencé a escribir y a publicar desde el año de 1928. Teníamos, con Clotario Maldonado, un periódico que se llamaba El Heraldo del Sur. Desde allí construimos las primeras armas y dimos los primeros pasos, por manera que esto era la vocación de escribir, y la de contar. Se puede deber a una cuestión hereditaria y, principalmente, atribuyo a que me impresionaba mucho la forma extraordinaria e instintiva que tenía mi abuela materna de narrar, era una contadora innata de cuentos, de consejos, refranes, de modo que eso influyó profundamente en mi ánimo y mi conformación intelectual. Bueno, y lo de CorRerías..., tiene su valor, tiene su mérito si así lo quieren reconocer. Todo trabajo intelectual que lo haga el hombre, merece las atenciones que el caso lo amerite. 
1930:

- ¿Cuándo nace su éxodo desde Loja a otras ciudades del país?

-"Viajé a Quito y allí apenas pude conocer la capital de nuestro país. Pude constatar las diferencias de desarrollo; se observaba, de manera especial, cómo se iban polarizando una y otra ciudad del Ecuador. Mientras en Loja no teníamos casi nada de adelantos, en Quito, las cosas marchaban de otra manera".

"Cuando fui a conocer Quito, me suscribí a la comida en una casa, en donde comíamos muchos lojanos. Costaba treinta sucres la comida cada mes: con ello se compraba café, almuerzo y cena, de vez en cuando una merienda". Pasé en Quito dos meses, justamente, conviviendo con los hermanos Mora Reyes. Ellos, por ejemplo, tenían muy buenos libros que yo me pasé devorándoles. Ya le dije, comíamos en el mismo lugar; por eso hubo la posibilidad de hacernos más amigos.

Más tarde comíamos en la Asociación de Empleados. Allí costaba más dinero, unos 45 sucres aproximadamente por mes; pero la comida era muy buena. "Hoy las cosas se han complicado. La devaluación monetaria se acelera todos los momentos. Se suma el abuso de los distribuidores. Antes la gente era muy sencilla. Los ricos vivían como pobres, a la espartana, y los pobres vivíamos nuestra pobreza".

Empero, la realidad fue cambiando, ha ido cambiando: gobiernos tiranos, incapaces, regímenes que cumplían consignas extrañas, sistemas injustos y opresores hicieron de nuestra humana realidad un mundo de dificultades, sufrimientos, pesares, penalidades; poco a poco se sentían las confrontaciones. No se respetaba el principio universal de que todos los hombres somos iguales y, como tales, tenemos derechos a un mínimo de comodidades inherentes a la persona humana. La vivencia de estas realidades y las lecturas de autores y obras de pensamiento y doctrina socialista nos llevaron a querer cambiar la situación, que era injusta.

\section{1-1933:}

Escribe BANCA. Es su primera novela. Lo hace en Loja y termina de escribirla en la cárcel. Inicia la escritura de CuRIPAMba y llega a un estado bastante avanzado.

\section{4:}

Sale de Loja, y lo hace con destino a la ciudad de Guayaquil. 
- ¿Loja le fue una madrastra?

- Fausto, madrastra no es, necesariamente, la mujer que incomoda o daña. Yo no he tenido nunca madrastra. Mi salida de Loja no se debe a problemas ni sentimientos de afectividad, oposición o rechazo a nada... Tampoco fueron problemas de salud... Fueron los problemas de la supervivencia, las necesidades de trabajo, la necesidad de desarrollo, esas fueron las realidades que nos condujeron a buscar nuevos rumbos, nuevos horizontes...

- ¿Desde Palanda se ve mejor la realidad? ¿Se debe buscar la Nueva Loja?

- Quiérase o no hay un desbande individual o colectivo. No se estaba negando el amor a la patria chica. Se necesitaba vivir y trabajar en la profesión. No había ninguna posibilidad de vivir decorosamente en Loja. La profesión de abogado no lo permitía.

\section{8-1940:}

BANCA se edita entre estos años, en Quito, en la Imprenta Fernández. [Jorge Fernández, es autor de la novela AGUA y de los cuentos ANTONio ha Sido una hipérbole. Por decisión y declaraciones de su autor, BANCA, se retiró de circulación, porque la edición contenía -es una verdad- muchos errores tipográficos.

\section{1-1942:}

Rojas sale muy temprano de su Loja natal. Se integra con mucha entereza y dedicación al trabajo literario en la ciudad de Guayaquil. Perteneció al notable "Grupo de Guayaquil", cuya visión del mundo y de la realidad nacional asimiló con un existencialismo estoico y lleno de expectativas y proyecciones, puesto de manifiesto en sus escritos y actividad proselitista, como miembro y secretario del partido Socialista, con las consabidas consecuencias de persecución y encarcelamiento entre 1941 y 1942, en el gobierno de Carlos Arroyo del Río, cuya política y gestión internacional, Rojas cuestionó con espíritu combativo y frontal, ante los resultados desastrosos para la integridad territorial del Ecuador. Una respuesta combativa, a través de la cual defiende la integridad territorial de nuestra patria, está dada en su ensayo El ECUADOR ENTRE COLOMBIA Y Perú [1980, la edición]. 
-iQué contradicciones, Dr. Á. F. Rojas, se restringe su libertad, porque un hombre como Ud., grita con voz firme la defensa de la integridad de nuestra heredad territorial!

- ¿En la cárcel, tal vez le recordaron esto?:

“¿Por qué vienes a llorar en la cárcel donde muero?

Carbonero, déjame a solas pensar,

por la sangre de tus venas,

si no me quitas las penas,

no me la vengas a dar".

- ¿El pensamiento de los hombres de izquierda de la época no cuajaba definitivamente?

El alistamiento en las filas de los movimientos revolucionarios de una gran cantidad de intelectuales, escritores y artistas sensibles a las injusticias sociales fue, como es sabido, una de las características de la vida política en los años sesenta. Ciertamente, la gestión humana, se acentuó en estas fechas. En nuestro país, el movimiento adquirió ribetes de mucha seriedad desde 1926, a raíz del nacimiento del partido. Impulsados por la necesidad de una perentoria transformación de la sociedad que perpetuaba las desigualdades, y guiados por el viejo principio iluminista, que con total anticipación a lo de la Revolución Francesa, se da en tierras de lo que más tarde será Ecuador, con nuestro Espejo. Todo esto es retomado por la izquierda, según el cual los intelectuales son la vanguardia de la historia, muchos hombres de letras y artistas de entonces decidieron tomar parte en la lucha política contra el sistema. En ese contexto algunas teorías estéticas comenzaron a defender una fuerte convicción con rasgos de imperativo moral: los artistas comprometidos debían constituirse, a través de su propio quehacer específico, en vanguardia política de las masas. Para avalar esa convicción los marxistas de esos años solían apelar a un prestigioso antecedente estético-político: literatura y revolución, literatura y cambio. El teatro tuvo mucha influencia.

- ¿El teatro es uno de los máximos grados de socialización?... ¿Por eso lo de la pieza "Guárdate del agua mansa" en el contexto de EL ÉXODO DE YANGANa? 
- Todas las partes, géneros, estilos, estructuras de la literatura en una obra, tienen su función y engranaje y apuntan la consecución de los objetivos, como se acostumbra a decir...

- La Revolución Francesa, de la cual ha hablado Ud., como el antecedente e influencia obligados para las necesarias transformaciones sociales, es un producto burgués y de la aristocracia. En este mismo contexto, ¿qué ocurre con el teatro?

- Yo no sugiero ni hago teatro burgués. Somos claros en el asunto ideológico. La burguesía ha cambiado el mundo profundamente, solo que ahora ya no tiene interés en que se sigan produciendo cambios. Y para conservar lo que tiene, la burguesía le pide al teatro que no la inquiete. Por manera que, en el teatro burgués las situaciones de cambio representaron y representan meramente "un malestar rápido entre dos momentos de calma".

- ¿Es confiable el proceso de concienciación social devenido de los intelectuales?

-Se han dado muchas cosas en este terreno. El movimiento de los años treinta con la literatura es confiable plenamente. El caso anterior de D. Juan Montalvo es decisivo, orientador, aleccionador. Socialmente la literatura de los años treinta, lo ha hecho con mucho vigor, tanto en la Sierra como en la Costa. Jorge Icaza, por ejemplo, entre otros, ha concienciado el proceso de la reforma agraria. En esta materia no creo que haya escritor de muestras parcelas, que con su literatura, se ponga a condenar esta necesaria realidad. El Grupo de Guayaquil, lo ha hecho en muchos otros órdenes que son de nuestro dominio. En el ámbito mayor de América Latina, las concepciones comienzan a cambiar. Hay necesarias variaciones. Pensemos en el hecho y actitud de los cubanos Guillermo Cabrera Infante, novelista, y Herberto Padilla, poeta que, de la militancia revolucionaria pasaron al rechazo de la misma y al exilio voluntario, actitudes que han destacado con nuevas escrituras y textos. Hay otro caso reciente: lo de Mario Vargas Llosa que, por mucho tiempo, abrazó la causa revolucionaria a través de su literatura, y ha trabajado mucho en ese orden. Empero, más tarde, lo rechazó. Sin embargo hay que estar seguro de algo: ninguna literatura deja de tener su rango social. 
- ¿Hay que desconfiar de los intelectuales? -¿Nacen abrazando una causa social de aceptación y terminan rechazándola?

- No es posible ser terminantes con las respuestas. En el mundo ideológico de la cultura hay de todo. Unas ocasiones si, otras veces no. Por ejemplo, desconfío de los intelectuales que desde hace treinta años no hacen sino propagar las rinoceritis y sostener filosóficamente las histerias colectivas de la cual periódicamente son víctimas pueblos enteros. ¿Acaso no fueron los intelectuales los inventores del nazismo? Si yo opusiera una ideología ya hecha a otras ideologías ya hechas que entorpecen nuestros cerebros, no haría sino oponer un sistema de eslóganes rinocerónticos a otro sistema de eslóganes rinocerónticos... Me parece ridículo exigir una Biblia a un escritor, a un político, o cualquier medio de salvación; es ridículo pensar y proveer para toda la humanidad de una filosofía automática. El escritor plantea problemas que los espectadores, en su recogimiento, en su soledad, deben pensar y tratar de resolver para sí con toda libertad. "Una solución defectuosa que haya encontrado por sí misma es infinitamente más valiosa que una ideología ya hecha que impide al hombre pensar".

Admitamos que en los sesenta el compromiso del escritor debió expresarse en una opción política clara y distinta. Preguntémonos qué se debió hacer en los años treinta y revisemos también qué se hizo, en la misma época, por la transformación social de los pueblos de nuestra patria. En el país, en los noventa, pese a no haberse dado una literatura representativa, después de la confiscación del reino de lo no real, ¿qué hizo la oposición?, ¿por qué se ha dado el rechazo a la absorción de la "otra dimensión" por el estado de cosas dominante, más omnipotente hoy que antes?

La literatura, al ser un compromiso con lo imaginario, ¿deja de ser, a la vez, un compromiso político? La toma de partido estética y política de hoy es guerra al arte dirigido, guerra al arte conformista, al arte massmediático convertido en artículo de consumo, al arte integrado, al arte-mercancía que se deja seducir por el susurro de los cantos de sirena del mercado, para después inclinarse y ponerse de rodillas. Desde luego la situación de los escritores y artistas que rechazan lo existente puede ser desalentadora, pues sus obras padecen la imposibilidad de producir efectos sociales. Y eso se debe a que la oposición al sistema dominante 
supone una renuncia al empleo de los medios de comunicación que justamente pueden llevar a producir esos efectos. El artista, decía Schiller, es hijo de su tiempo "pero desdichado de él si, a la vez, es su alumno o incluso su favorito". Aquellos que esperan conseguir la eficacia que echan de menos gracias a una adaptación a las necesidades existentes yerran el rumbo. Y en primer lugar porque, como decía Adorno, no sabemos cuáles son las necesidades, pese a los especialistas y eruditos en arte y a los expertos de la industria de la cultura. No hay duda de que el arte entendido como Gran Rechazo se encuentra malherido. Las hienas y los chacales sienten el olor de su sangre. Su ausencia hace pensar que está confinado en algún sitio apartado, y allí se lame las heridas y resiste contra la muerte anunciada por el demonio del mercado. Es verdad que la lección de Adorno tiene algo de llamado a una heroicidad de la que muy pocos son dignos. Y que sus palabras pueden sonar, en los oídos realistas y pragmáticos de los ' 90 , como un rumor de los espíritus de los extintos dioses de la utopía, o como los estertores finales de los últimos románticos. Pero, tal vez, el verdadero y profundo realismo no sea el de la banalidad de la sensatez y el sentido común del rebaño que se doblega, sino el de aquellos que son capaces de soñar. "Seamos realistas, -se decía en mayo del '68-: pidamos lo imposible.

1944:

En 1944 fue Secretario de la denominada Alianza Democrática Ecuatoriana (ADE) y después del triunfo de la Revolución del 28 de Mayo, fue nombrado Contralor General de la Nación. En la misma época desempeñaba la cátedra en la Universidad Central.

\section{6:}

- YY cuándo decide venir a vivir en Guayaquil, en esta ciudad que le ha acogido?

- Por la misma época que conocí Quito, me di saltos a Guayaquil. Con esta ciudad fue 'amor a primera vista' y me quedé a vivir en este puerto ecuatoriano. A raíz de la Revolución de Mayo interrumpí mi estancia en Guayaquil, para de aquí ir a vivir en Quito. Fueron dos años. Como yo era militante disciplinado del socialismo, las bases del partido y los dirigentes me impusieron que fuera a desempeñar el cargo de Contralor General de la Nación. Me pasé en la capital dos años como tal, hasta 
cuando el Dr. José María Velasco Ibarra cometió la barbaridad de proclamarse dictador. Esto fue el 30 de marzo de 1946. En esta fecha, con una renuncia bastante enérgica, les tiré el cargo; pasé unos meses en Quito para luego instalarme definitivamente en Guayaquil.

- ¿Y su trabajo profesional de abogado, Dr. Ángel Felicísimo?

- Por mi amistad con Pepe De la Cuadra conseguí vincularme al trabajo de abogado. Él me invitó a participar de su oficina pública, de su consultorio. Fui a trabajar con él. Pasó un tiempo, dejé de ser invitado, y nos convertimos en socios. Pepe tuvo que abandonar el consultorio; yo lo retuve por un tiempo más y fui, afortunadamente, el amigo que le ayudó en los últimos días de su vida tan trajinada y tan malograda. Por desgracia se dedicó a la bebida. Muere prematuramente a los treinta y seis años de edad.

- Su tiempo y trabajo de escritor de y en la soledad, ¿cómo lo compartió con los amigos de la generación?

- Fui amigo de todos ellos. Con Pablo Palacio, que casi siempre vivió en Quito, no tuvimos tantos vínculos. Cuando publicaron mis escarceos literarios, Pablo me escribió felicitándome El último en morir fue Alfredo Pareja Diezcanseco. Las reuniones de los amigos del grupo de Guayaquil y de los compañeros de generación fueron muy disciplinadas. Tuvimos una vida agitada, de muchas preparaciones, de muchos debates, de organización de frentes para combatir dura y tesoneramente al régimen injusto que actuaba bajo consignas y manipulado por los grandes intereses de capitalistas, de hacendados y de oligarcas; acciones de estos que siempre lo hacían en contra del pueblo. En mi caso personal, después de la Revolución del 28 de Mayo, mi vida política fue menos activa.

En el campo de la creación literaria, con el grupo de Guayaquil, hubo comunicación muy fluida. Eran francos, directos, extrovertidos. Ellos creían que yo tengo buen juicio crítico, y me mostraban también lo que ellos estaban haciendo. Nunca tuvimos choques, peor grados de enemistad. Las observaciones que les hacía, si las consideraban fundadas, las tomaban y esos niveles de comunicación nos permitían crecer mutua y solidariamente. Su aceptación y respaldo me hacían tener confianza en 
mis juicios. Creo que en algo he contribuido con ellos, me parece que mis modestas sugerencias les han servido en algún grado en la construcción y concepción de sus textos. Me llenaba de satisfacción el caso de Demetrio Aguilera Malta, un escritor hecho, un escritor consagrado, dentro de sus andanzas por Brasil o México, venía a verme y me hacía conocer sus trabajos.

- Tengo una anécdota con Demetrio. Le observé sobre los planos narrativos. Que se escriba de conformidad con la moda de nuestra época, que no se incursione en lo otro, no por desconocimiento o por falta de competencia. Por el contrario, porque ese era el mejor vehículo de expresión en el cual dábamos lo mejor de un pensamiento, imagen y comunicación. Le sugería que siguiéramos escribiendo en la forma en que creo que fue nuestra época más lúcida. Demetrio -y está bien, lo hizo muy bien- se fue más allá. No en vano es el representante del realismo mágico, del realismo fantástico; porque la no linealidad del discurso literario le ayudó a conseguir otros objetivos y logros.

- Dr. Ángel Felicísimo, -de regreso al factor ideológico- sin embargo, su obra no se enfrenta con fuerza contundente en contra del poder agresor. Ideológicamente hay mesura, no hay cuestionamiento al poder capitalista afuereño, no hay la denuncia in extremis, como lo harán los compañeros de su generación, como lo quiso y demandó el autor de LAS CRUCES SOBRE EL AGUA -Joaquín Gallegos Lara-, nada de manera franca y frontal, como denuncia en contra de los integrantes del imperialismo de Tío SAM. Un perro -un latino, un ecuatoriano- se enamora de la luna -de ella que es ciudadana de los EE.UU. No se pierde la memoria de un pueblo, del pueblo de Yangana, gracias a la presencia del extra$\tilde{n}$ o, del gringo investigador y científico, de míster Sparck, y su historia de amor con Juanita Villalba -escéptica y triste-. Se da una integración.

- Sí, Fausto. Es que no se puede descender al trabajo de una literatura de cartel. Con ella no formamos ni construimos nada. Hay que educar con altura, con profundidad, con entereza, con seguridad. Por supuesto que también hay que enseñar la ideología política. Pero la agresión, el odio, el veneno nos destruyen, nos matan. El mundo le ha ubicado al poder capitalista en el lugar que le corresponde, y de alguna manera lo sigue haciendo. Sabe y conoce en dónde está ubicado el poder imperialista. 
Esa lucha de cartel, necesariamente, no es tarea del escritor. El escritor debe ayudar a construir las patrias. La concienciación de los grandes sectores sociales y populares, es una de las tareas del escritor, sin descuidar que siempre se estarán buscando las libertades y ayudando a construir esa libertad de la manera digna. Y es esa lucha, cotidiana, esforzada y perseverante, la que pone de manifiesto el mérito y grandeza de nuestra profesión, de la cosmovisión del escritor.

- La casi sempiterna cuestión de la crisis de la novela tal vez se deba a que siempre ha sido el género de contornos más difusos, el más abierto, dúctil y maleable, en permanente renovación de unas señas, que el siglo $\mathrm{XX}$ en particular demostró, que eran marcas de época, de tendencias compositivas o estéticas o de concepciones autoriales y, por tanto, no definitorias de lo novelístico. $\mathrm{O}$, en nuestro país, de lo que va el movimiento de la literatura, de lo que se dice con la llamada nueva literatura, lo del siglo XX ideológica, técnica y culturalmente asoma como lo definitivo. No dudo que pueden venir las nuevas propuestas: sin embargo, la novela se marcará en términos de novela, el relato se hará en sus propios medios, la poesía igual. Piense lo mismo del ensayo. Variarán los conceptos que, sin lugar a dudas, también estarán en función de época y movimientos...

- La literatura, como es de su dominio, ha dejado de ser el reducto por excelencia en el que habita la invención y ha modificado su status ficcional, en un proceso de convergencia paralelo al que describía Steiner, para transformarse en reportaje, en crónica, en testimonio de valía historiográfica.

- Por otra parte, en nuestro país, en la América Latina, y en el ámbito de lo que se ha dado en llamar "tercer mundo", la literatura ha cumplido una reconocida función social, que muchos de estos autores reivindican de forma explícita. Cada país, cada nación es rico o rica en ejemplos que ha dado la literatura, como el mayor grado de concienciación social. Ha evidenciado los desgobiernos; asimismo ha orientado procesos perennes de enmienda de esos regímenes.

- Pensemos y revisemos lo que hace Agustín Cueva Dávila en su libro inicial: ENTRE LA IRA Y LA ESPERANZA. Nos está dando a entender que 
los libros culminantes de la cultura de cada país se consideran con la seriedad y la cursilería del caso, retratos de familia y nación y cumplen también funciones reservadas a la sociología, la psicología social, la historia.

- En diferentes niveles, desde el costumbrismo a lo mítico, esta dimensión gnoseológica de las formas narrativas ficcionales y de la novela, ha prevalecido, muchas veces, en detrimento de su consideración como productos estéticos.

- Desde estos supuestos, acudo al término de compromiso para señalar el vínculo que estas obras establecen con la realidad inmediata y, mediante el cual, la escritura se torna una vez más en un medio de conocimiento o en una herramienta para ejercer la crítica o la denuncia sin paliativos, aunque ambas, a mi parecer, se realizan más desde una disidencia moral que desde una posición ideológica concreta.

- Nuestro compromiso de escritores no se reduce -no es su dimensión, ni se puede reducir- defectiblemente en solo un compromiso con un partido, un gobierno o un grupo ideológico, sino en la comprensión más abarcante de la historia. Pero la historia aquí, como puede deducirse, no es el pasado en el que se ahonda para hallar las claves de comprensión del presente, ni es tampoco la instancia abstracta que registra hechos y figuras consideradas como relevantes y memorables para una determinada comunidad.

Esta noción de historia es la que propicia que otros seres y sucesos se queden fuera de ella, sin lugar ni tiempo, sin entidad ni nombre. Tampoco se trata solo de revelar la verdad silenciada, sino de poner en entredicho el concepto de realidad en que se sustenta la versión oficial, en el convencimiento de que esa realidad es más compleja, múltiple y diversa de lo que el reduccionismo de cualquier versión puede mostrar.

- En las literaturas nacionales de los países hay de todo. Desde dentro o desde fuera, los autores reconocen abiertamente que sus obras suponen una respuesta al intento de negar o de orientar la violencia política del país y, en ese sentido, sus aspiraciones de historicidad (o de constituirse en una alternativa del relato oficial y, por tanto, en documento) no admiten duda. 
En Ecuador, la literatura no ha negado ni ha escondido el proceso de concienciación social. Los escritores de nuestro país, como destaco en LA NOVELA ECUATORIANA, en el afán de cuestionarse la realidad tienen especial empeño en mostrar que lo que se toma como existente, real o verdadero es también una construcción imaginaria -tal vez utópica- de complicidades múltiples, con lo que las posibles fronteras que separarían la verdad de la mentira, la realidad de la ficción están borradas de antemano.

- La construcción y la constitución ideológica es decisiva a través de la literatura. ¿Qué pasa con los silencios de compromiso? ¿Se justifica, entonces, el virtual silencio de Pablo Palacio, dado el requerimiento "gallegiano" -me refiero al de Joaquín Gallegos Lara- que su pluma por la dirección e imposición totalitaria- tenía que ensayarla y prestarla para las grandes causas sociales del proletariado ecuatoriano?

- Los miembros de un partido tuvimos y tienen que respetar, disciplinariamente, las directrices que manda, pide y ordena la fuerza de una tendencia. No cuanto en tanto debamos condicionar los componentes del hecho literario. La literatura y el escritor deben mantener y cultivar su libertad. Pablo ganó en trascendencia lo que no hemos ganado los demás. Por manera que, su literatura no deja de ser política. Se da una fina y muy inteligente construcción política. Efectivamente, la posta de la polémica la tomó Jorge Hugo Rengel. Allí está su libro REALIDAD y FANTASÍA REVOLUCIONARIAS que resume todos los acontecimientos de Joaquín Gallegos Lara con Pablo.

- Ahora que nos hemos referido marginalmente a Pablo Palacio, ¿de veras murió pobre y abandonado aquí en la ciudad de Guayaquil?

- Lo de pobre económicamente es el fatalismo de los escritores, porque ni la fama soluciona nada. Pero, Pablo Palacio, que fue traído bastante enfermo por su mujer, es un caso especial. Nunca estuvo abandonado. Nosotros sus amigos nunca le descuidamos. En alguna medida le asistimos hasta su muerte. Por manera que Pablo tuvo sus amigos hasta el final de su vida. Además, Pablo Ayala Cabanilla, dueño fundador de una clínica psiquiátrica recibió a Pablo por una pensión menos que simbólica. Se sabía quién es Pablo Palacio. 
- Es de dominio casi público la crisis económica en la que quedó Carmita, su mujer. Los medicamentos que administraban a Pablo demandaban mucho dinero. Los amigos poníamos cantidades de dinero para paliar en algo. Solo así saldábamos las cuentas que por fármacos necesitaba cubrir Pablo. Ciertamente, los recuerdos y nuestra memoria comparaban el Pablo deshecho, terminado y consumido por la enfermedad con el Pablo de plenitud de inteligencia, por lo que, me resistía a visitarle -aunque nunca dejé de hacerlo- siempre salía de su lecho del dolor y de la muerte muy deprimido.

- En este campo, ¿qué conoce Ud. sobre los ascendientes -sobre sus padres- de Pablo Palacio?

- Considero que un análisis sobre estos particulares, no acrecienta ningún valor a la obra de Pablo. Por manera que le invito a que centremos nuestras atenciones en la obra que Pablo ha podido dar, y a la que modestamente hemos podido aportar.

- Quiero recurrir y recordar esta vez las expresiones y conceptos de María Luisa Puga: "La novela sabe ya que su denuncia es parte del gran ritual vacío. Los libros más certeros en contra del sistema son al mismo tiempo las cartas fuertes culturales que el sistema prodiga a la población en ejemplares económicos y con tirajes masivos. Ese libro en el puesto de periódicos, al alcance del lector más humilde, forma parte del paisaje retórico que ha engendrado la indiferencia en la gente. Con un reducido umbral de lectores y con la experiencia de un sistema que, al menos hasta ahora, ha sabido asimilar la discrepancia como justificación de su necesidad, pueden convertirse en banderas de una conciencia histórica que a nadie afecte. Tremenda paradoja esta y de ser cierta e irresoluble, la evidencia de un fracaso".

- Muchas veces, en fin de cuentas, antes la ficción ha sido tomada como mero vehículo de representación, el ropaje que no impide tratar en términos de verdad aquello de lo que se habla y donde, a menudo lo novelesco: la trama, los personajes, el argumento, y fuera de lo puramente novelesco, los recursos estilísticos se han supeditado al rigor documental o se han reducido a su mínima expresión, cuando no eliminado, para no inducir al lector a creer que se encuentran ante una simple novela... 
- Al estilo de Mario Vargas Llosa, la novela, el relato, ¿"son mentiras sabiendo qué es lo que se miente"?

- El carácter ficticio de la narrativa novelesca radica no en lo que tiene de verdad o de mentira, sino en lo que tiene de verdad evidentemente falsa o de mentira cuya transparencia la anula como tal mentira. Si no aceptamos este principio, que nos permitiría referirnos a ellas como novelas, habremos de buscar otro nombre para designarlas. Si lo aceptamos, su dimensión testimonial, y sobre todo documental, no debe ensombrecer su consideración de productos estéticos hasta el punto de desvirtuarla. La documentación en la novela no implica convertirla en documento. Los recursos y artificios narrativos no solo pueden aportar múltiples puntos de vista y penetrar en las capas más profundas de la conciencia individual y social, sino que es posible también desvelar motivaciones o aventurar juicios, más o menos implícitos, que serían inadmisibles en otro tipo de discursos, porque solo al novelista, en cuanto hacedor de ficciones, se le exime de justificaciones sobre lo narrado. Lo real se opone a lo ficticio o a lo supuesto porque en lo ficticio nada está sujeto a prueba de verdad, ni a pruebas de contraste siquiera. Por eso, aunque los sucesos, los escenarios y los personajes sean comprobables, literariamente esto no tiene importancia. Y desde este supuesto se ha convertido en ficción, muchas veces, la experiencia personal, como un recurso de salvaguarda, y se ha renunciado a otras formas literarias que se apoyan en la memoria. Por eso, y porque el tratamiento propiamente novelesco, posee unas condiciones de universalidad de las que están exentos el reportaje periodístico y el ensayo, cuando se refieren a hechos singulares.

\section{3:}

Desde 1983 adquirió la membresía de la Academia Ecuatoriana de la Lengua correspondiente de la Real Academia Española de la Lengua de Madrid.

1993:

- De regreso a Ángel Felicísimo Rojas, ¿cuándo se da la escritura de sus textos, de la literatura, de la creatividad? 
- Cuando el tiempo de defensa vital y de supervivencia me lo permiten sigo escribiendo. Decía el Papa Juan XXIII: "El hombre tiene tres maneras de arruinarse: las mujeres, el juego y la agricultura, y mi padre escogió la menos divertida de las tres y se hizo agricultor". Yo también me hice agricultor y terminé con mi economía. Por manera que debo seguir viviendo de mi profesión de abogado. Fuera de la profesión, cuando ella me deja libre, escribo. Ud. conoce algunos documentos.

Después de las presentaciones de la segunda edición de Banca y la primera de CuRIPAMba que las hizo Ud. en Loja, aquel ofrecimiento de hace más de una década, lo de EL BUSTO DE DOÑa LEONOR está listo. Hay algo más: "Fachas, fechas y fichas". De alguna manera hay un modesto aporte de seguimiento al enfoque de lo que se hace en La Novela eCUatoriana, con los dos ensayos que Ud. conoce: "La novela de los últimos años: Temas, tendencias, procedimientos" (1978), "Preliminares para un ensayo sobre Literatura lojana" (1983). Tengo el boceto de una nueva novela.

Trabajo sobre una propuesta de novela: EL CLUB DE LOS MACHORRos. Pero sigo con el periodismo. Así me inicié en los periódicos de Loja, sobre todo en El HERALdo DEL SUR, en las revistas que son de su conocimiento. Mi literatura, los capítulos iniciales de BANCA y de UN IDILIO вово, comenzaron a difundirse, más tarde en las páginas literarias de El TelÉGrafo de esta ciudad. Hago periodismo en las páginas editoriales de los diarios El Comercio de Quito y en EL UnIVERso de Guayaquil, y lo hago para mantener la práctica constante, sobre todo para no olvidar la redacción.

- Ángel F Rojas es un periodista que enorgullece a los ecuatorianos que conocemos sus columnas en las cuales vierte su opinión y pensamiento. $\mathrm{Su}$ sagacidad y trato del lenguaje lo hacen caso aparte. No en vano es miembro de número de la Academia Ecuatoriana de la Lengua, correspondiente de la Real Academia Española de la Lengua de Madrid.

De un tiempo para acá, el periodismo se ha convertido en un género de ficción por la ligereza de muchos periodistas que se vanaglorian de estar conectados con las altas esferas del poder (como si esto fuera un reconocimiento de su valía) y pretenden conocer de primera mano todo lo que se dice en la oficina, en la alcoba y hasta en el mingitorio del Señor Presidente. Si los periodistas hacen novelas, los novelistas tenemos 
derecho a buscar la verdad con nuestros propios artículos. Si se escribe periódicamente, entregando colaboraciones en los periódicos del país, es para hacer presente las opiniones, los criterios que pretenden guiar a grandes sectores populares que buscan orientación en los medios de comunicación. También se escribe con la finalidad de practicar el ejercicio de la redacción.

\section{5:}

- ¿Qué pasó con su casa en Loja, la casa que la tenía a la altura de los dos puentes, en Cajanuma, vía Malacatos y Vilcabamba...?

- Fausto, la tenía. No sé quién... Desconozco quiénes... la saquearon, la dejaron sin los utensilios que en ella estaban... se ha hecho por varias ocasiones... Esa acción me ha provocado una duda profunda sobre el respeto que la gente debe prodigar a los demás. El inmueble lo vendí y eso y mi edad me alejan un poco más de la tierra...

\section{7:}

En 1997 recibió el premio Eugenio Espejo del gobierno nacional.

\section{0:}

- Estoy recordando las preguntas que J. P. Sartre se plantea en su libro ¿QuÉ es la literatura?: “QQué es escribir?”, “Para qué escribir?” y “Para quién se escribe?”. Quiero repetirlas a Ud., Dr. Á. F. Rojas.

- Dicho de un modo ligero y sencillo, se escribe para un público. Sin embargo esta es una afirmación muy sencilla, porque los textos que escribe el escritor, que los prepara, que los crea, los textos que los expone van más allá de un destinatario. Cada texto es una realidad política, una realidad ideológica; se trata, cada vez de una construcción; a través de ellos se trabajan los procesos de formación y cambio sociales. No necesariamente la construcción de los textos de la literatura se los apunta de una manera cerrada para un público y para un mercado. Sin duda, convendría señalar las diferencias entre el público y el mercado. Si bien no creo que sea este espacio el más apropiado para meterse en esas honduras, sí me parece necesario indicar que el concepto de público contiene aunque sea muy débilmente la conciencia de "bien público" mientras que el concepto de mercado solo atañe a satisfacción de necesidades privadas. Por otra parte, la materia literaria está conformada por elementos 
de carácter público: palabras, historias, convenciones literarias, estéticas, criterios de verosimilitud, presuposiciones narrativas, etc. y en ese sentido el escritor trabaja con materiales públicos, de ahí su responsabilidad. Con razón se dice que los textos literarios construyen una realidad autónoma respecto a la realidad real, que a su vez es una construcción social determinada por el desarrollo histórico, científico y cultural de la sociedad. Pero que la literatura sea autónoma no significa, como a veces parece quererse dar a entender, que sea independiente. En última instancia las palabras hablan de la vida y por tanto los textos literarios producen ideología, es decir, visiones del mundo, escalas de valores, sensibilidades, subjetividades colectivas, sueños, deseos, juicios, tareas, miedos y expectativas. Y eso lo hace fuera de la voluntad del escritor.

Esto conlleva a ver y a aceptar, quiérase o no se quiera, que los textos siempre dan testimonio de la sociedad que los produce y consume. Sin embargo cuando se habla -se hablaba porque actualmente se habla poco- de literatura y testimonio de lo que realmente se estaba hablando era de la necesidad de que los escritores dieran testimonio en sus libros de determinadas realidades que determinados poderes políticos trataban, y tratan, de ocultar o distorsionar.

Es decir, el concepto de testimonio se establecía como voluntad política. Al día de hoy, el reclamo de esa voluntad parece haberse disipado y tal desaparición podría tener su origen en los siguientes fenómenos: las democracias capitalistas son hoy ideológicamente hegemónicas y por lo tanto su discurso se presenta como no cuestionable y por lo tanto no hay hueco para más realidades que las que ese discurso ofrece; la ideología literaria dominante rechaza, con repugnancia estética, cualquier imposición de tareas a la literatura que no sean las que esa ideología le impone y entre sus imposiciones ha logrado establecer que cualquier relación entre literatura y voluntad de testimonio es mala para la primera, y por último y acaso el más importante; dar testimonio implica dar testimonio ante alguien, ante algún juez más o menos determinado que esté juzgando, valorando pruebas por tanto, para resolver alguna acusación. Pues bien, en mi opinión no existe hoy ningún juez de este tipo.

- Por otro lado, la desaparición de la escena política de la lucha de clases y de los proyectos transformadores ha diluido la posibilidad, al menos a corto plazo, de esa instancia acusadora. La metáfora de Suku- 
yama sobre el fin de la historia encerraba un juicio claro; definitivo y final: la realidad actual está bien y en cualquier caso es inocente. Las democracias occidentales se han juzgado a sí mismas y se han encontrado inocentes.

Caído el muro de Berlín y sin proyectos transformadores que cuestionen el sistema ningún recurso de apelación ni juicio alternativo alguno es posible. Por tanto, nadie podría acusar hoy a ninguno de dar una visión parcial de un problema narrativo: Por ejemplo, desde el ámbito de la novela, ¿se puede abordar narrativamente la legitimación de la clase capitalista sin dar el paso narrativo necesario a los afectados por esa legitimación? Ningún juzgado aceptaría a trámite tal querella porque la doctrina actual no considera este hecho como un problema narrativo. Sobre el término compromiso habría, en primer lugar, que situarlo históricamente. El concepto de compromiso que Sartre teorizaría de manera espléndida en su texto ¿QUÉ ES LA LITERATURA? -una pregunta que no estaría mal hacerse de vez en cuando- si bien tiene su origen en la Revolución Soviética y en la Guerra Civil Española, corresponde al momento concreto de la guerra fría y está relacionado con la necesidad de tomar partido en aquella situación concreta. Creo, por tanto que su utilización hoy solo puede crear confusión. Con todo, quisiera volver a recordar que lo importante de cualquier compromiso es que comprometa, es decir, ponga en riesgo nuestra situación, nuestro status social o profesional, nuestro sueldo. Comprometerse con los pobres del mundo, los refugiados serbios o kosovares no es hoy ningún compromiso. Entre otras cosas porque si no cumplimos con nuestros compromisos nadie nos lo va a echar en cara. El compromiso solo tiene sentido si alguien puede reclamarnos su cumplimiento, de ahí que frases como "compromiso con la literatura", o "compromiso con el lenguaje" no dejan de ser farfullas retóricas, vacías, aunque "estéticamente correctas". El que sí está "comprometiendo" a los escritores de hoy es el mercado, pues más o menos explícitamente nos hace saber que quién no siga sus reglas está condenado a no existir. Quién no vende no existe decía hace poco el escritor Manuel Vicent. Y tenía razón aunque, qué le vamos a hacer, no nos aclaró a qué le llama existir. No vaya a ser que aceptemos confortablemente que el mercado sea el dueño, también, del significado de esa palabra. 
2002:

- BANCa, como novela, más allá de ser la novela de juventud, ¿es la proyección revolucionaria del hombre, es la lucha por la construcción de una ideología del mismo hombre, pero es también el trabajo de concienciación que deben hacer los líderes en la medida de la transformación de los pueblos ante el horror de la opresión de la tiranía de los regímenes...?

- La edad y la efervescencia revolucionaria tocaba a las puertas de las aulas y los deseos de las movilizaciones populares creaban las condiciones, para que los estudiantes de aquella época mirásemos a la sociedad ecuatoriana como una quimera, donde era posible realizar todos los sueños. Los acontecimientos, por manera que, muchas veces opacaban la posibilidad de un análisis sereno de la coyuntura, precipitando a veces, la acción colectiva.

De aquellos sueños impregnados de ideas de cambio social despertamos aturdidos por la violencia y la guerra. Estamos viviendo las secuelas de la Primera conflagración mundial. Vivimos el horror de la guerra fría. Vivimos la construcción liberal y laica de este pueblo. Vivimos las historias que nos cuenta Joaquín Gallegos Lara. Vivimos todas las pretendidas reconstrucciones.

- ¿Entonces, cuál es la esperanza, Dr. Á. F. Rojas?

- Nada menos que la posibilidad de la organización social. Obnubilados por el horror, los estudiantes de aquella época tomamos diferentes caminos, tal vez por ello, al caminar por la senda de la ideología y del trabajo político mi intención sea recordar rostros olvidados, lugares y tiempos, olores y colores que tuvieron un significado en nuestras historias de vida. Eso también es BANCA.

Otra razón sería de naturaleza coyuntural, por la importancia que tiene conocer y proceder a "desmontar" la institucionalización de la contrainsurgencia, y la creación de un Estado de Derecho con plenas garantías ciudadanas para la gente de mi patria.

Fuimos una elite intelectual. La elite es un grupo selecto de personas que se reúne para trabajar en equipo, son individuos representantes de diversos sectores sociales o de grupos de personas que ocupan puestos estratégicos en organizaciones poderosas que tienen poder y que toman decisiones. 
Es en el momento en que se reúnen y trabajan colectivamente, cuando se consolidan como elite, construyendo a partir de determinadas prácticas políticas, de la creencia generalizada en ciertos valores y en la estipulación de reglas, que legitiman su poder, su status y privilegios frente a los subordinados.

- ¿Es el trabajo de vanguardia, Dr. Ángel Felicísimo...?

- Puede serlo en el mundo de las convenciones...Pero yo, no utilizo el concepto de vanguardia revolucionaria, porque él tiene una connotación política, enfatizando en aspectos ideológicos, mientras que el de elite es suficientemente flexible para incluir a grupos de personas, que disputan frente a otras elites los recursos disponibles.

- ¿Repetiría la experiencia de retornar a la vida pública administrativa, para caminar por las veredas y aceras de la burocracia?

- ¡No! ¡Nunca! [Medita sobre la forma violenta que dio la respuesta. Por eso, a continuación reacciona de otra manera.]... O tal vez, es posible... Depende nuevamente de las circunstancias, uno tiene que estar en guardia en esto, las generaciones nos preceden y nos siguen. Pero, no se va a estar eternamente de protagonista en todo, el tiempo pasa [se ríe] y hay que dejar el paso también a los jóvenes.

Los señores Fernández son los hijos de Jorge Fernández, el autor de la novela AGUA y de otros relatos. [Ud. llevará hoy una copia de ese trabajo]. Con los señores Fernández guardo un entrañable sentimiento de afectividad, me propusieron el cargo de rector de su Universidad. Fausto, ya no se puede aceptar. Son muchas las razones que a uno le impiden aceptar. Es la edad, la falta de experiencia en cargos administrativos para una dirigencia universitaria, la modernidad de la administración... Ya no se está para eso. Les agradecí con mucho reconocimiento de gratitud por la deferencia con mi persona.

- ¿Ud. sirvió la causa burocrática en el gobierno del Dr. José María Velasco Ibarra, hacia 1946, como Contralor General de la Nación?

- Sí. Fueron dos años. Como yo era militante disciplinado del socialismo, las bases del partido y los dirigentes me impusieron que fuera a des- 
empeñar el cargo de Contralor y me pasé en la capital dos años como tal, hasta cuando el Dr. José María Velasco Ibarra cometió la barbaridad de proclamarse dictador. Es una experiencia dolorosa que sigo sin superar por las circunstancias mismas.

- Ud. se desafilió del Socialismo. ¿Por qué? ¿Hubo un giro de gestión ideológica en su persona?

- Nada de cambio personal de giros ideológicos. Ahora, con la madurez que se sigue construyendo, soy acaso el socialista más convicto adonde puede y pudo llegar un hombre como yo. La crisis ideológica del partidismo y de los grupos políticos ahora es mayor que ayer cuando decidí salir de las filas del socialismo. No se puede ver ni se puede esperar, desde las filas de un partido político, un reducto y un campo solo para protervos fines de lucro y desarrollo personal. He meditado seriamente en la actitud ideológico-política de Pablo [Palacio]. Esa historia la conocemos. Frente a la corrupción uno desfallece ante la necesidad de sacar fuerzas para gritar duro. Creo que el silencio, como el de Pablo, es lo mejor para seguir construyendo las patrias.

- ¿Dr. Ángel Felicísimo Rojas, cuál identidad se preserva? ¿Cuál identidad permite vivir en un medio hostil? ¿La que fue o la que es? Aún existe un vacío en la bibliografía ecuatoriana sobre el exilio romántico y el choque cultural que significa volver en sí al país y readaptarse a la cultura que se dejó atrás. BANCA es un exilio voluntario e individual. EL ÉXodo de Yangana es otro exilio, pero social. En tanto que CuRIPaMBA supone ya la defensa de una identidad. ¿De qué identidad estamos hablando?

- Si..., pero no tanto. Otra dimensión de la identidad es la colectiva, la del país, cuya definición provoca un profundo debate y las más apasionadas reacciones en tanto que significan la toma de posición personal frente al otro. Es un problema -el del de las tensiones entre campesinos e indígenas frente a la clase media alta, la burguesía y aristocracia que ostenta y ha sustentado el poder- que debe verse a la luz de la lucha de clases. Lo que nos divide no es lo étnico sino lo de las clases sociales, nos une más con los indígenas la explotación que lo que nos divide a los indígenas con los mestizos. La discusión interna sobre el papel revolu- 
cionario de los indígenas por serlo, está superada, hubo mucha mitificación de eso y la situación actual demuestra que eso era absurdo. Los indígenas, absorbiendo todos sus valores culturales, tienen que integrarse y no disgregarse en procura de pretensiones de gobierno aparte. Por manera que llegaríamos a la polarización étnica de etarras y no etarras de lo que actualmente se hace en España. No se puede hacer nada importando otros ejemplos que no enseñan nada. Eso destruye.

- ¿Pero, cómo pudieron perderse estructuras y coyunturas en el proceso social? ¿Por qué no se ha podido aprovechar el naciente problema revolucionario -háblese de concienciación- con Espejo en tierras de lo que más tarde integrarán el Ecuador, o ya en la misma vigencia de Ecuador como tal, desde el movimiento de los indios, con el romanticismo montalvino, con la situación de Riofrío, con lo de Juan León Mera Martínez, etc.? Se lo digo esto, porque ustedes estuvieron más próximos de la posibilidad de reconstrucción que nosotros...

- La verdad que no, yo no creo que ese haya sido digamos...[pausa], planteado así, la presencia de una dirigencia mestiza...[pausa], a mí me choca utilizar el concepto indio, lo creo igualmente racista y despectivo, entiendo que sí fue un factor determinante la ausencia de la consideración del carácter del país, del carácter de la nación dentro del proyecto revolucionario, entonces no lo veo, digamos, estructuralmente en el sentido de cómo se componía, cómo se conformaba la revolución, sería como decir no hubo una conducción esencialmente proletaria y por eso fracasó el movimiento comunista en el país y si hubiese sido solamente proletaria o hubo predominio del campesinado y por eso fracasó, creo que plantearlo...[pausa] es decir...[pausa], analizarlo dentro de los elementos de la ausencia de éxitos del proyecto revolucionario solamente desde la óptica étnica creo que para mí es limitar y sesgar de manera unilateral la visión de lo acontecido.

- ¿Por qué el fracaso comunista en el país o en Loja? ¿Lo de "Alfaro vive, carajo" -en el ámbito nacional ecuatoriano-fue otro buen intento? Un poco antes, respecto de Loja y del país, recordemos los análisis sentidos en esta materia lo que hace el gringo Albert B. Franklin en: ECUADOR: RETRATO DE UN PUEBLO. 
- Lo de "Alfaro vive, carajo", no creo que sea un intento de organización socialista del Ecuador. La acción del gobierno nacional por combatirlo a ese movimiento guerrillero, me parece que fue positiva. Su acción, su clandestinidad, presencia y permanencia en el país -el no haber hecho nada para erradicarlo- pudo desembocar en lo que han desembocado movimientos afines en muchos países del mundo. Por otro lado, el fracaso del proyecto comunista en Ecuador, se debe a la escasa presencia de militantes de origen obrero y campesino, cuya ausencia siempre ha sido notoria en todos los momentos de decisión política del país o, porque los obreros no se integraron, o porque ellos no se prepararon, o porque ellos no se capacitaron. La conducción de las organizaciones revolucionarias no estuvo en manos de aquellos por los cuales se luchaba y las elites -revolucionarias o no- no conocían su opinión sobre qué tipo de cambio deseaban, hacia qué dirección y cuánta cantidad de cambio era necesaria para construir una sociedad mejor, y fundamentalmente, cuál sería el costo del sueño revolucionario.

- Para Ud. Dr. Á. F. Rojas, que fue militante de izquierda, ¿qué es una elite revolucionaria?

- La elite, es un grupo selecto de personas que se reúne para trabajar en equipo. Son individuos representantes de diversos sectores sociales o de grupos de personas que ocupan puestos estratégicos en organizaciones poderosas que tienen poder y que toman decisiones. Es en el momento en que se agrupan y trabajan colectivamente, cuando se consolidan como elite, construyendo a partir de determinadas prácticas políticas, de la creencia generalizada en ciertos valores y en la estipulación de reglas, que legitiman su poder, su status y privilegios frente a los subordinados. Dr. Aguirre, se debe tomar en cuenta un aspecto: no utilizo el concepto de vanguardia revolucionaria porque tiene una connotación política, enfatizando en aspectos ideológicos, mientras que el de elite es suficientemente flexible para incluir a grupos de personas, que se disputan frente a otras elites los recursos disponibles.

- En El Éxodo de Yangana, don Vicente Muñoz, "el hombre más ilustrado de Yangana", "el afectuosamente llamado Chapetón", entre líneas de la narrativa, es el líder académico que orienta un proceso de transformación. ¿Esto es lo que ha fallado en la trasformación de nuestras realidades hacia el socialismo? 
- El argumento académico es útil contrastarlo con los testimonios escritos por antiguos líderes y guerrilleros. La evidencia encontrada en las fuentes escritas nos conduce a conjeturar que progresivamente las organizaciones revolucionarias se iban transformando en organizaciones elitistas en los niveles de mando. A pesar de la incorporación masiva de militantes de base y de colaboradores, la cúpula se iba restringiendo, ello podría explicarse a partir de las condiciones de clandestinidad y secretividad; por manera que, los mismos actores señalan la concentración de la toma de decisiones y de prácticas políticas ajenas a un código de conducta democrática que expresara un consenso entre las elites políticas, que desde diferentes organizaciones conducían el proceso revolucionario o de transformación: desde 1895, con el triunfo de la Revolución liberal, o con la organización del Socialismo, como partido político, desde 1926, en nuestra realidad ecuatoriana. Los dos hechos de nuestra historia nacional, posiblemente, en los ámbitos de la literatura, han motivado la escritura de los mejores textos: novela, cuento, poesía y ensayo.

- No solo Fausto Aguirre le ha reclamado, le ha demandado al Dr. Ángel F. Rojas, sino intelectuales que trabajan de veras en la crítica han reclamado esa continuidad. Considero, con la honradez mayúscula, que el estructuralismo realmente ha representado la muerte del lenguaje y el análisis y la crítica continutista que se ha apoyado fundamentalmente de la mano con la realidad y con la significación de la realidad de la época, es la que ha sustentado la interpretación de nuestra cultura, de modo que, el estructuralismo más que moda ha sido apenas una cuestión pasajera que realmente no ha dicho nada, sino ha definido una muerte de las estructuras. En este contexto, a Ud. como escritor, como novelista, como hombre de pensamiento, ¿qué opinión le merece la actual política, la actual realidad que vive nuestro país?

- Este total desconocimiento, porque, ante la incertidumbre de queremos y no queremos incorporarnos, nos dejamos absorber por una corriente que parece irresistible que es la globalización. Y queremos también aplicar políticas económicas que nos imponen el tener que dividir a la población en clases implacablemente distintas. Yo creo que lo que nos espera, lo que les espera a ustedes, gente joven todavía, es un gravamen de la situación humana, porque esta globalización trata de imponernos el sistema que suprime todo subsidio, que deja a la economía en manos de los 
tiburones, creo que nos va a conducir a una tremenda situación que agrava las tensiones y que crecerá el hambre. Salvo que un sistema -antes de aplicarnos la teoría de Malthus-, casi tiránico, vaya imponiendo la limitación de la población. Un neo maltusianismo que es la única forma de conseguir que los recursos, que genera el hombre que puede trabajar, alcancen para mantener un cierto decoro no animal a la gente que no encuentra trabajo. Porque la tecnología va eliminando brazos. Al ser humano se le acaba el mundo.

- Las gentes de los hacinamientos, de los suburbios, los de bajo nivel económico en que viven, primeramente son de una fecundidad alarmante que se explica por qué la naturaleza, en ese sentido, obra produciendo fertilidad para evitar que la especie desaparezca. Por algo Darwin decía que la naturaleza es madre de la especie y madrastra del individuo. Procura defender la especie aún cuando degenere y el hombre que no alcanza a alimentarse con cierto sentido práctico, alimentarse en forma suficiente va produciendo una degeneración gradual. Y como a su vez se reproduce con esa facilidad que la naturaleza le da está en trance de desaparecer.

La siguiente masa humana asomará como una generación que biológicamente rinde muy poco. No va a resistir y no va a rendir nada.

Los médicos y los trabajadores de la salud se han cansado de demostrar científica y demográficamente que esta población crece en forma indiscriminada. Es una población que si no está bien alimentada, vendrá el individuo con taras desde que nace. A su vez, dentro de algunos años, es seguro que genéticamente conduzca a la degeneración. Entonces, esta es la triste situación que yo veo venir porque nosotros somos un país que crece como crecen los demás países pobres, en una forma indiscriminada, sin que hayan los medios necesarios para dar trabajo, para darle alimentación, para darle techo... Los que aspiran la burocracia y los actuales demagogos ofrecen soluciones, pero saben que no lo podrán hacer. Esto mantendrá en la peor indigencia a la sociedad y a sus congéneres.

Desde el ámbito de sus análisis, ¿se puede entender y comprender, entonces, el porqué de la delincuencia y todas sus facciones aunque no se pretenda justificar? 
- Sí. Pero los gobiernos y regímenes son los que ponen a la sociedad en ese plano.

2003-07-19:

"iQuien nada debe, nada teme!".

-¿Quién mató? ¿Cómo y por qué le mataron a Á. F. Rojas?

- Murió mi hijo. Un periodista informó -creo que a diario EXPRESO"Que el hijo del Dr. Á. F. Rojas ha muerto". "Solo se captó la expresión "ha muerto el Dr. Ángel Felicísimo Rojas". Desde diario EXPRESO -creo también- que se comunicó a diario Hoy que el Dr. Á. F. Rojas ha muerto. Hubo muchas notas fúnebres por la desaparición del Dr. Rojas. Me di cuenta cómo sería la vida postmortem de Á. F. Rojas: Pero, "el muerto que vosotros habéis matado -utilizando la frase de Rómulo Gallegosaquí está "vivito y coleando" y goza de pleno estado de salud".

- ¿Cómo murió el Dr. Á. F. Rojas?

- Estuvo conversando. Se sentía cansado. Dijo: -"Quiero descansar". Pero los robles no mueren, ahora más que nunca se pone en vigencia el pensamiento del hombre. Muere -de un infarto- en la ciudad de Guayaquil: 19 de julio de 2003, 93 años de edad.

$* * * * * *$

Hasta aquí he mostrado vivencias, escenas, pasajes, conceptos, ideas, opiniones del intelectual, del hombre escritor, del hombre político, del hombre maestro, del hombre que marcó una dimensión intelectual. Con seguridad es eso lo que pude plantarle al Dr. Á. F. Rojas, mientras lo pude hacer. Debo confesar que mientras estuve varias ocasiones, con grabadora en mano, al frente de su persona, y lo he hecho por más de un cuarto de siglo 1972-2002, actué con restricciones; las manifesté, demostré celos, temores, timidez, falta de decisión para plantearle situaciones eminentemente humanas. Fundamentalmente, respeto. Sin embargo, como testimonio de una realidad que complementa la visión del hombre hermano, del hombre papá o padre, abuelo, bisabuelo, amante, están, por ahora, su hermana, doña Enriqueta Aguirre Rojas de Cueva 
y el Dr. Jorge Luis Rojas, hijo, quien cariñosamente se refiere a él como el doctor Rojitas. Volteemos la página.

- ¿Qué es el Dr. Ángel F. Rojas? ¿Quién es? ¿Cómo lo ve Ud. al Dr. Ángel F. Rojas, a su hermano, o al margen de que él sea su hermano?

- Un hombre maravilloso. Como hermano ha sido un guía en nuestra vida, de mis hijos, a quienes quiso mucho. Estuvo tan unido a nuestra vida. Nos separamos cuando yo me casé, pero él siempre me visitaba en Loja, lo hacía todos los años, todas las veces que podía, porque quería mucho a su tierra y nos quería mucho a todos nosotros. Después fuimos a Quito y allá siguieron nuestros contactos familiares. Continuaban nuestras relaciones fraternales. Yo iba unas veces a Guayaquil adonde él estaba, pero siempre estuvimos unidos por los lazos familiares. Era y hubo un cariño entrañable, por eso es que he sentido mucho su partida. Doy gracias que pude estar los últimos días recordando nuestras épocas pasadas: cuando vivía nuestra madre, nuestra abuela, mi hermana, y fueron recuerdos, los más dulces que llevaré toda mi vida.

- ¿La madre del Dr. Rojas?

- ¡Ahhh!, mamá Filomena.

- Sí, Filomena, ¿y doña Justa?

- Era una tía. Si, la tía Justa.

- ¿Y la abuela?

- Mamá Gertrudis.

- ¿Cómo era mamá Gertrudis?

- Era el centro de atenciones de todos quienes vivimos con ella. Era una señora que contaba cuentos maravillosos en esa época...

- Bien, Jorge Luis, ¿cómo lo ve Ud. al doctor Rojas, al margen de que Ud. sea su hijo? 
- Bueno, yo lo vi siempre como un amigo, como una guía, como un ejemplo, y creo que esos sentimientos los llegué a compartir muchos momentos con él, sobre todo cuando yo ya tenía una mayoría de edad, una madurez. Porque cuando uno es niño al papá lo ve como papá. En esa época, los padres, no son como ahora, que juegan, que se ponen a hacer niñerías... En esa época, por lo menos, él actuaba así, y uno siempre lo veía con respeto, simple y llanamente.

- Era parco, difícil, actuaba en un mundo de una situación vertical.

- Definitivamente sí. Entiendo que esa su actitud se debió... a que también él fue criado sin su padre, por un lado y educado por su madre que tenía que hacer las veces de padre y madre. Cuando crecí, y me daba cuenta de muchas cosas, le hacía compañía cuando viajábamos a visitar sus tierras, su hacienda. Eso fue sucediendo desde que yo me acuerdo, desde cuando yo tuve trece años de edad -más o menos-. Lo acompañaba siempre, salíamos cada dos semanas, y salíamos para revisar, vigilar y controlar el avance de las labores agrícolas... Cuando él no lo podía hacer personalmente, por a o $\mathrm{b}$ motivos, me delegaba para que yo vaya a hacer los pagos a los jornaleros, para que vea los trabajos, etc.

- El Dr. Rojas papá, indudablemente cumplía las funciones de tal: vertical, duro, difícil, sabía educar al hijo Jorge Luis cuando no asistía al colegio, cuando, sin motivo ninguno, abandonaba... ¿Qué hacía el Dr. Rojas cuando sabía que Jorge Luis incumplía?

-Cuando él sabía que yo me 'hacía la pava', como se llamaba en esa época, de no asistir a clases, me preguntaba si yo había ido al colegio. Como desde niño no me gustó mentir, le decía la verdad, que me había hecho la pava... Entonces era un castigo seguro. Mi padre fue un sólido ejemplo de lucidez, trabajo y honestidad hasta el final de sus días...

- A pesar de que hubo una situación hogareña de diferentes matrimonios, el padre no descuidó nunca su responsabilidad de estar junto a su hijo, de apoyar una educación... Sin embargo, ¿es Jorge Luis el que más tarde estaría en compañía permanente de su padre?

- Sí, efectivamente, nosotros vivimos con él... Hasta que yo recuerdo, vivimos con él hasta el año 1960, fecha en que él se divorció de María Eugenia Flor Ayala.

208 
- ¿Tuvo hijos con ella?

- Sí, con ella tuvo dos: mis dos hermanos menores, el uno José Ernesto Rojas Flor que falleció hace 7 años, y mi tercera hermana: Martha María Rojas Flor, que dicho sea de paso le salió "curuchupa" [conservadora, católica]. Ella se enroló en el Opus Dei.

- ¿Es la hija que quiso 'convertirle’ al cristianismo al Dr. Ángel Felicísimo Rojas?

- Bueno, siempre pretendieron, su nieta incluida, María Asunción, pero no lo lograron...

- ¿Lo veían un elemento peligroso ideológicamente a su padre, abuelo o bisabuelo?

- ¡No creo! Eso ha cambiado en la época. Simplemente, sus nietas, querían que su abuelito se vaya al cielo...

- ¿El que concurría a la iglesia iba al cielo?

- No sé si el que iba a la iglesia, iba al cielo o al infierno, pero en todo caso..., ese era el pensamiento y la actitud de sus nietas. Ese era el criterio que tenían. El Dr. Rojitas fue agnóstico [del agnosticismo: Doctrina filosófica que declara inaccesible al entendimiento humano toda noción de lo absoluto, y reduce la ciencia al conocimiento de lo fenoménico y relativo], pese a que su familia materna era muy cristiana, muy religiosa: mamá Gertrudis, mamá Filomena, y lo mismo Delita y Ketyta [hermanas del escritor].

- Doña Enriqueta, a pesar de que el Dr. Ángel F. Rojas abandonó muy temprano la ciudad de Loja..., como buen lojano, jamás dejó de pensar en la tierra, siempre vino a Loja, siempre retornaba a Loja y estaba con sus hermanos, con los parientes...

- Sí... Toda la vida. Él, su recuerdo lo tenía en Loja. Como él decía: "vivo allá, porque quiero mucho a Guayaquil, pero mi corazón lo tengo en Loja". Guayaquil le dio mucho. Eso era lo que él siempre decía. Que- 
ría mucho a su tierra, a sus parientes, sus amigos. Cuando venía a Loja los buscaba. Siempre que llegaba los buscaba para estar en camaradería con ellos. Definitivamente, en Loja no tenía ningún interés de tierras, de agricultura, nada; le atraía la situación de familia. La situación de lazos afectivos, nada más.

- Sr. Víctor Flavio Cueva Ontaneda [esposo de Enriqueta Aguirre Rojas], ¿cómo lo vio Ud. al Dr. Rojas? ¿Cómo lo solía tratar?

-Yo lo conocí al Dr. Rojitas, desde cuando era yo muy joven... Era mi profesor en el Colegio Bernardo Valdivieso, allí nos conocimos. Era una persona muy dura, recta, tenaz, muy justa, era una persona verdaderamente maravillosa.

- ¿El Dr. Rojas fue un verdadero amante del amor y de la vida?

- Sí, él amó la vida siempre. A mi hermana María Elena y a mí él nos había hecho creer que él moriría muy joven... Más de una ocasión nos dijo que él se moriría a los 40 años. Y con María Elena recordábamos eso, cuando estábamos con nuestro padre en las últimas semanas y decíamos: El Dr. Rojitas decía que se iba a morir cuando era joven y fíjate tú, nos ha acompañado toda una vida.

- ¡Un siglo de existencia!

- Sí... Él amó la vida y amaba a todas las cosas que ella conlleva. Sobre todo al sexo femenino. Ha sido muy amante del sexo femenino.

- ¿Qué conoce Ud. de esas andanzas del Dr. Á. F. Rojas, de las andanzas por el amor, por los intereses del sexo femenino? ¡Si no lo es una delación, por favor, Jorge Luis!

- No, de ninguna manera. Eso fue público y notorio... No fue ningún secreto. Él era un hombre que se dejaba... que se dejaba querer. Si de los hombres se dejaba querer, imagínese qué sería de las mujeres... ¡Cómo no lo amarían!

- Pero, ¿Ud. como hijo fue muy celoso de las andanzas amorosas de su padre con otras mujeres que no fueron con su madre? 
- ¡No! ¡No, no!, son asuntos demasiado personales de cada hombre, de cada persona. No creo que los hijos debamos prejuzgar ni prejuiciar las cosas de los padres. Ni como hijo, ni como hermano. Ni como marido soy... no he sido celoso. A estas alturas de la vida creo que tampoco llegue a ser.

- Doña Enriqueta, Ud. como hermana, desde su visión de mujer, ¿cómo ve esas andanzas de afectividad, en el hombre Ángel F. Rojas, con otras personas, con y en otras realidades?

- Bueno, él sí tenía muchas admiradoras, muchas... Por ejemplo, en el Normal Rita Lecumberry, en donde fue profesor, algunas... muchas profesoras estaban detrás de él, se interesaban por él, se insinuaban siempre, y él era muy generoso..., muy amoroso, muy afectivo.

- Cuando venía a Loja en programa de visitas -y él concurría periódicamente a esta ciudad- ¿qué es lo que hacía el Dr. Ángel F. Rojas en Loja?

- Se reunía con sus amigos, y tuvo muchos amigos. Provocaba reuniones con unos e igualmente asistía a otras que le invitaban otros amigos. También visitaba a las amistades que las teníamos desde hace tiempos. Tenía sus días con la familia Vélez con la cual se llevaba muchísimo: Vélez y Ledesma, que eran Vicente, Servio, Clotario Maldonado, también se reunía. Muchos de ellos eran compañeros de generación. Se reunía con la familia Witt con la cual tenía muy buenas relaciones. Él los iba a visitar. Llegaba aquí en Loja y visitaba a todas estas familias.

- ¿Ese vínculo con la familia Witt creció en Portovelo, tal vez en la explotación minera?

- En Portovelo... Sí tenía mucha amistad con Ernesto...

- Ernesto, ¿era el abogado de la empresa?

- Sí. De la empresa. Él pasaba... íbamos a pasar, de vez en cuando, allí dos días, en Portovelo. Él tenía una hija llamada Lucrecia, que también él le admiraba. Se interesaba mucho por la Lucrecia Witt. Era una mujer muy linda e inteligente. Íbamos a visitarla en Portovelo. 
- ¿Y es que Á. F. Rojas fue muy temprano, antes de ser abogado, fue a trabajar en Portovelo?

- No. Él no trabajó en Portovelo, dice Enriqueta Aguirre Rojas de Cueva.

- ¿Fue amanuense -o algo por el estilo- de alguna de las maneras en una estancia vacacional en Portovelo? Más tarde, esto le va a motivar su novela CURIPAMBA.

- Sí recuerdo que él me decía..., perdone que le contradiga, Ketyta. Mi padre había ido a ayudar en una dependencia de Portovelo, aprovechando, precisamente, de esa relación que tenía con don Ernesto Witt. ¿De Curipamba? Ahí nació algo relacionado con la novela, por su paso por Portovelo.

- ¡Exactamente! Mientras eso lo hacía en la ciudad de Loja, ¿qué es lo que hacía en Guayaquil cuando se reunían los fines de semana o todas las ocasiones con sus hijos o con Jorge Luis, específicamente, y con los hijos de Jorge Luis?

- ¡Ah!, ya. Eso es mucho más moderno. Tuve yo la suerte de que en mi casa se reunía toda la familia; y muchas semanas, también los días sábados, compartíamos y disfrutábamos de la compañía de mi papá y de su esposa, Maruja Pérez.

- ¿La última esposa?

- Sí, la última, efectivamente. Disfrutábamos mucho. Él -incluso- nos recordaba muchas cosas de las que había vivido en su juventud en Loja. Una de las que recuerdo, por ejemplo, era que su amigo... Tenía un compañero que era un diablillo que en la novela BANCA lo conocen como el pequeño Neptalí, pero que en realidad ese pequeño Neptalí, no es el pequeño Neptalí, pariente que vivía en Taxiche.

Yo descubrí que el pequeño Neptalí no era el pariente. Se trataba de Enrique Guerrero Varillas. De eso me enteré hace muy poco; se lo conté a mi tía Ketyta, quien también pensaba que Neptalí de BANCA era nues- 


\section{RECTORADO}

Turuhuayco 3-69 y Calle Vieja

Teléfono: +5937 2863040 • Fax: 2861750

e-mail: rpublicas@ups.edu.ec

www.ups.edu.ec

Cuenca - Ecuador 